\title{
Between Calls: Together in the Garden
}

Camilla Bostock and Sarah Jackson

BOSTOCK, C., JACKSON, S., 2019. Between Calls: Together in the Garden. Parallax, 25 (3), pp. 333-350. [doi: 10.1080/13534645.2019.1624327]

\begin{abstract}
Composed of a series of missed telephone calls, our paper attempts to both recall and preserve Hélène Cixous' contribution by telephone from her garden to the 2018 symposium in Nottingham on the 'Unidentifiable Literary Object'. Observing that Cixous' first manuscript 'arrived like a meteor' in Derrida's garden, we gather together our recollections of the lost call, entering Cixous' 'real garden' on a bird's wing in order to explore the relationship between the animal, the vegetal and the human. Reading fragments from Cixous' oeuvre, and drawing in Derrida's own conversations with Cixous, we interrogate what happens in language between two interlocutors on the telephone, listening together (with death between us) for scraps of conversation from the ephemeral anemone to the magnolia in full bloom.
\end{abstract}

\section{Keywords}

unidentifiable literary object; telephone; garden; flight; ephemeron; death; Cixous; Derrida 


\title{
Between Calls: Together in the Garden
}

\author{
Camilla Bostock and Sarah Jackson
}

SJ : : :

Camilla, I'm sorry it's taken me so long to get in touch. I've not known where to start the call, or how to speak. It's more than the matter of address. And now I've missed you, and my only option is to leave you this message.

You will know this, of course, but we were due to contact HC by Skype at $2 \mathrm{pm}$ on the day of our symposium on the ULO: a computational call with no obvious mouthpiece, it would be an open line, with all those ears listening in. ${ }^{1}$ We had asked for her permission to record the Skype conversation, an audio-visual reminder of her absent-presence at the event. But at 10.31 am on 29 June 2018, I received the message on my mobile: 'Okay things don't look good for the internet here', Eric wrote. 'Seems like it's a big problem in all of Arcachon, and now they say it will be fixed by tomorrow morning! Maybe we could try the telephone?' I signalled you with my eyes then: did you hear me? Later, two technicians placed the telephone at the front of the seminar room and plugged everything in. It was a land-line, they insisted, but that was hard to believe: a three-pronged listening machine with lights at the tip of each wing that pulsed green when a connection was made, it seemed ready for take-off. And despite our best laid plans, we'd have to call her up on this unidentifiable flying object.

It could have been a dream, of course, telephoning HC, who so often speaks of, to and at this machine. You know that I've been working on this, on all the calls that structure her work. Recalling her telephonic relation to Derrida in Insister of Jacques Derrida, she writes: '- I imagine one day, he says, researchers, students will write theses on the telephone chez Cixous and chez Derrida, that is, in the texts, because there are many telephones in the texts, they are everywhere, everywhere'. ${ }^{2}$ Everywhere, everywhere. Even here, in Nottingham, on 29 June 2018. But I would never be ready for this.

CB : : :

Sorry I missed your call, Sarah, and for not ringing back sooner. I'm trying to generate some sort of callback, perhaps by way of recalling that other missed call with HC. Listening to your message, I remember it so vividly: that unaccountable three-petalled callbox, the unidentifiable telephonic object, which, to me, after the event, came to resemble a magnolia flower in full bloom. I recall and yet the call is irretrievable, it has become a kind of lost artwork, remembered only on my memory-pad in a few scrawled snippets. And yet, meagre as they are, these traces seem to live on, they're getting to work as we speak, conjuring all manner of trickery and sorcery, through time and space, like fragments of a prehistoric script. Everywhere, everywhere. Perhaps that's what we'll come to call them. I'll try you again later.

SJ : : :

But our call - whatever its format - was always going to have an uncertain ring. Eric was still en route to France, HC had been travelling, and we knew she was concerned about her cats. 
We tried to test the software with Eric the previous week, but the connection was beset with errors, the wrong address, a missing licence, and a satellite that wouldn't transmit. It was my nightmare: always trying to dial the number, never getting through. And there I was again: staring at our UFO, our blooming magnolia planted on the table before me, trying to work out how to operate the dial. Remember the narrator's encounter with a mobile phone in Love Itself in the Letterbox? 'This little jewel is recalcitrant', she writes: 'In vain I key in the formula, it remains unmoved'. ${ }^{3}$ That was how it felt. I remember, too, that in Love Itself a stranger offers a hand - 'she specializes in these little objects', she says, and the narrator admits that 'in my confusion, I entrust the little one to her'. But in a flash, she says, the lady has 'gone off with her loot'; contact has been cut, and 'Now here I am voiceless. So close to you. And like someone with a slit throat'. ${ }^{4}$ Trusting neither the internet in Arcachon, nor the technicians in Nottingham, and feeling so far from getting through, my throat was cut. And it was as if $\mathrm{HC}$ already knew, had written in advance the scene in Love Itself.

'Now I am approaching the Hour', she writes: 'In two minutes you will enter your office. Your telephone will ring. It will be my voice'. ${ }^{5}$ We played out the scene, don't you think? It was five to two and people were filtering in. In a few minutes her telephone would ring. I imagined the little jewel placed in front of her. I thought I knew from Love Itself what happens next, but I didn't expect to be so touched by her laughter on the line, by the sound of her 'six hundred voices'. 6

We wanted to ask, of course, about the telephone. 'It was inaugural', she said to us down the line: 'I was always aware of the telephone'. But, she went on, 'It has grown and become more conspicuous'. 'What an instrument the telephone is! What an angel! What a demon!" she writes elsewhere. ${ }^{7}$ Drawing out the literary economy of the phone, she told us that day: 'Literature calls. [It is the] most natural metaphor for what happens in books'. Literature works like a telephone, she said: 'It calls. Or doesn't. It hangs up.' At least I think that was what she said, for we have no record, and in my notebook I can no longer tell whose voice is whose.

So these calls are really about our lost call - the call of which we have barely any trace. It is, in many ways, about the absence of our call, the secret call that we cannot recall. But for all its absence, this is the call that calls on us to call to each other - the call to write. As HC says to her beloved in Love Itself: 'Without the Absence-of-Telephone would you have ever written me the letter of June 17, 1966, which will later become The Letter of Fate? ${ }^{8}$ Without the loss of our own telephone call, would we ever call to each other like this?

\section{$\mathrm{CB}::$ :}

I've missed you again. I feel the miss of it, like the touch of a phantom limb. I meant to ask you earlier: do you know the term for a 'missed call' in French? They call it un appel en absence; a call in or of, or even to absence, an absent call. But whose or which absence does this refer to? The absence of the called? Or the caller herself? Or some other, somewhere else? The experience of the impossible: to receive a call, the record of a living voice, from someone who is no longer, or never was, present. Every time - I miss you.

This lost or missed call - I've begun to think of it as an ephemeral being: literally, an

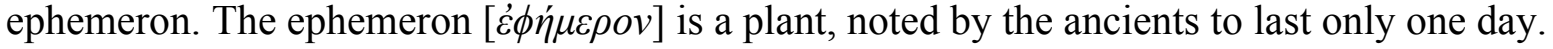
An ephemeron is also, as Aristotle notes in History of Animals, an insect, which he calls 
'dayfly' because it lives for less than twenty-four hours in its winged state. ${ }^{9}$ The day in question, the day of our ephemeral call, was filled with winged beings, flying saucers, lines of flight, feathers of laughter that travelled from Arcachon to Nottingham at the speed of light. Don't get me wrong, I'm not speaking here of the living voice - the voices-from-afar of Hélène and Eric - that all calls necessarily employ, but rather of a kind of non-voice that the telephone brings into play. It's no coincidence that ephemeron - the name of a being already inscribed with its own absence, playing, from birth, at the edges of death and forgetting contains the word phone.

(I'll say this silently: already, from the start, there's something between us. A wire, line. Yet also something missed. A mist? Death itself, perhaps. No, that comes later. Let's save that for the end.)

I will try to speak a little clearer, for I want my call to be picked up one day. In a footnote to Dissemination, Derrida recalls the fate of Adonis who, after Venus became infatuated with him, was hunted and killed by jealous Mars and turned into an anemone as he died. Derrida notes that 'anemone' is a flower of the breath and brevity: the Greek word anemone means 'windflower', so called because the flower is said to open only when the wind blows - thus only when it is filled with an ephemeral breath. ${ }^{10}$ The anemone does not last long and bears no fruit, making it useless in agricultural (which is to say, human) terms. As such, it becomes associated (like Adonis himself) with the 'weak, easily exhausted, superfluous seeds giving rise to ephemeral produce (floriferous seeds)'. This is opposed to the 'strong, fertile seeds' used and produced by agriculture, which engender 'necessary, lasting, nourishing produce (fructiferous seeds)'. ${ }^{11}$ In Ancient Greece, the words 'Gardens of Adonis' were used to refer to something trivial and wasteful. During the festival of 'Adonia', which was celebrated by Greek women to commemorate and mourn the death of Adonis, small 'gardens', consisting of lettuce and fennel seeds, were planted in a meagre amount of soil in fragments of broken pottery. These sprouted briefly, then, unable to take root and grow, withered and died in their shallow graves. ${ }^{12}$

The ephemeral Adonis-anemone, who refuses to use his seed to reproduce with Venus, becomes aligned with what Plato (following Socrates) views as the wastefulness of writing. Derrida glosses the analogy deployed in the Phaedrus to oppose speech and writing: 'On the one hand, we have the patient, sensible farmer [...]; on the other, the Sunday gardener hasty, dabbling and frivolous. On the one hand, the serious [...]; on the other, the game [...] and the holiday'. On the one hand, we have the wasteful women, planting impossible, 'hasty' gardens in a few crumbs of earth; on the other, the 'Father' of the land, who watches over and tends his crops night and day. Speech, being tended and 'present', bears fruit, whereas writing becomes, Derrida concludes, 'a lost trace, a nonviable seed, everything in sperm that overflows wastefully, a force wandering outside the domain of life'. ${ }^{13}$ So, it seems we have planted our own commemorative garden - hastily, frivolously. Our call, the one we can't for the life of us recall, our missed trace of a ULO, is, right now, wandering, loitering, playing, outside - in the garden perhaps, untended and vegetating. We memorialise it here, with yet more wasted calls.

Before I go - an answerphone message is also an ephemeron. It is not intended to be saved or kept, being only, for the most part, a way of saying 'You missed me' or 'I missed you' or simply: 'I was here'. It's written, recorded, in place of the other's absence. You press 'delete' and it's gone. Listen, I hear myself saying into the machine, do you hear, I have mere seconds to say all that I need to, let them be well used, the time is so short and I'm trying to answer a 
billion calls at once here, in this very brief space of time, recalling those abstracts and brief chronicles of the time ${ }^{14}$ - bref, as they say - the time is now, be brief, I hear -

SJ : : :

Birdsong. For when we called that day, $\mathrm{HC}$ took us directly to her garden in Arcachon, to listen to a bird call. Forgive me, for I am still all over the place and up in the air, and although it is inevitably towards the garden that we are moving, it was the bird that I heard first and I just can't get it out of my ear. It transported me back to my first telephonic encounter with HC. In 2011, she was on the line to Nicholas Royle: were you there that day? ${ }^{15}$ I didn't hear the call, only its online trace, which makes the loss of ours resound all the more. But what struck me most was that the call was interrupted by birds: seagulls on the Sussex coast. 'Who's calling there?' she asked. 'It's a seagull,' he responded. 'Isn't that wonderful?', she exclaimed, 'She's phoning! And can you imagine that I get her call?' Cixous is always interested 'in a chain of associations and signifiers composed of birds, women, and writing'. ${ }^{16}$ And seven years later, the birds were calling again - this time from her garden. She asked us down the line: 'Can you hear?' From the mother-gull of the Sussex coast to the unidentifiable bird in the garden of Arcachon, birds are always on the wire. ${ }^{17}$ 'And what I would answer to the seagull', she said that day in Sussex, 'is yes, I'm here.' And what we said back to her down the line, on board the telephone, from Nottingham: Yes, we're here. We hear.

It has taken me such a long time to find my way here/hear, and now I find I remain suspended in full flight above the garden's perimeter. Like a bird on the wire, I am already half-falling. But there's something about this state of suspension that feels fitting. In 'Literature in Secret', Derrida refers to the phrase "Pardon de ne pas vouloir dire" translated by David Wills as "Pardon for not meaning (to say)..." - as a way of conceiving the status of 'nonknowledge'. ${ }^{18}$ Although the reader 'can understand its words and syntactical order', and although its 'movement of reference [...] is undeniable or irreducible', Derrida points out that the origin and context of this phrase can never be fully determined, and so the meaning of the text, its signatory and its addressee, remain suspended, or 'up in the air'. Crucially, however, Derrida suggests that it is this suspension of meaning that enables the phrase to approach the structure of literature: 'the absence a fully determinate context predisposes this phrase to secrecy and at the same time, conjointly, according to the conjunction that concerns us here, to its becoming-literary'. ${ }^{19}$ The literary object, therefore, hovers somewhere between the legible and the secret; without a fully determinable origin or context, it remains suspended, in flight.

But is there something else up there, up in the air? In his discussion of the suspended status of the secret, Derrida compares it to the voice of God which 'comes down upon us vertically like rain, like a meteor'. ${ }^{20}$ He goes on to suggest that the literary object has the potential to fall from on high, and thus can be considered 'a sort of meteorite'. ${ }^{21}$ This of course recalls his account of first reading HC's work as 'arriv[ing] like a meteor in my garden'. ${ }^{22}$ It is, moreover, an image to which he returns repeatedly, explaining it as 'a phenomenon, such as appears in the brilliance or phainesthai of light, produced in the atmosphere'. ${ }^{23}$ Charles Barbour points out that this particular image comes from 'the Greek meta, or over and above, and aoros, or lifted and hovering in the air'. ${ }^{24}$ The literary object is thus a phenomenon that appears only as it enters the earth's atmosphere: 'Up in the air, it belongs to the air, to beingin-the-air. It has its dwelling place in the atmosphere we breathe, it dwells suspended in the 
air even when it touches. Even where it touches. That is why I call it meteoric'. ${ }^{25}$ But, Derrida goes on, 'what is meteoric must be brief, rapid, transitory'; the meteor is 'at the outside of an instant' and can only ever be glimpsed in passing like a winged being or ephemeron. Moreover, the meteor's origins always remain unknown. Becoming luminous only as it enters our orbit, Derrida stresses that it arrives 'from who knows where'. ${ }^{26}$ The meteor, therefore, is akin to literary language; like a meteor or unidentifiable object that lands in one's garden, the literary refuses to reveal its own origin or context. Transitory and rapid, its referent remains up in the -

\section{$\mathrm{CB}::$ :}

Each time, our time is up too fast. Transitory, rapid, you say, and the beep comes to cut us off. The call, our little lost one, was also constrained - fifty-five minutes, from Arcachon to Nottingham, was all the time we had. Afterwards, we were almost overrun with rats and, before that, it was sandwiches, coffee, snatched conversations. You might have noticed that I'm no good at these things - I make for the door, scrabble about for an escape ladder. Nor have I ever been at home on or with the telephone. It's a kind of enemy of mine. Contrary to what Cixous says about the telephone being for life, a tool for deferring death ('for me it is life itself', ${ }^{27}$ she says to NR), it has always, for me, been contaminated by loss and waste. I waste away on the telephone.

But Cixous' insistence on warding off death on and through the telephone has got me thinking. You wonder, under your breath as it were, keeping the idea as a half-formed seed in the earth, if 'the telephone also has wings'. I'm reminded of the ephemeron, which lives for just a few hours, evading the inevitable by living quicker, flying faster. When Deleuze and Guattari speak of 'lignes de fuites' it is not only in terms of flying, but also fleeing, evasion, sidestepping. ${ }^{28}$ Do you recall the story Cixous related to us, on the line from Arcachon, of her mother, Eve, who wanted to cheat death by escaping along the forking branches of a magnolia tree outside her bedroom window? ${ }^{29}$ Perhaps we'll speak about that some other time. For now, what I want to say is that D\&G's lines of flight also give us tele-lines. Fugitive phones (like HC's mobile 'jewel' that leaves her for another. On this note, I might add that the jewel is also a play-thing - it comes from the French word jeu, meaning 'game, play'. So it's always playful-serious, this taking flight: an unmappable, dynamic, evercontingent game). We race towards the telephone, which escapes. That's what it's like talking to you on/with the answer machine. Here, too, I'm tracking something, some telesecret of yours, but before I know it, it wilts like an Adonis flower or adult mayfly, a shortlived ephemeron on its last lines. Much has been said, of course, about the quickness of HC's writing. It's a meteor, yes, a falling star: blink and you'll miss it. But it's also an escapee or deserter (at once brave and cowardly), making a bee-line for the exit. NR suggests that Cixous' idiom might be read through the single, untranslatable English word 'away'. ${ }^{30}$ Away's the dayfly, the awayfly, a fugitive force which lives-dies (and plays) on the wing, its secret going down with it. (A question, an aside: are we trying to cheat death by accidentallyintentionally missing each other like this? Are we afraid of who or what might be waiting at the end of the line?)

I'll ring off now. Call again. I know I'll miss it, will have missed it, by the time you call. Like I said, I'm no good on the telephone. I'll be out. Away. But, nevertheless, call again. 
SJ : : :

- air, as I was saying, right before we were cut off, before my message was suspended, midflight, mid-fall ... although I cannot be sure where that call landed, if it landed at all. HC's text arrives of course like a meteor in Derrida's garden. Leaving for now his question 'What is this?' 31 - fully suspended, to Derrida's text we might add, 'where is this?', for where is any telephone call?

I haven't yet thanked you for the way that you showed so tenderly how the botanical is cultivated in the text. But your call also suggested to me that in landing in Derrida's garden, HC's text exposes the garden as a 'place of relations', where the human, the animal, the vegetal and the mineral co-exist. ${ }^{32}$ Discussing HC's La, Calle-Gruber explains that her 'real garden' (that is, literature) is 'heterogeneous but not disordered, effusion but not confusion. It is movement that not only plants and grows, but supplants: all categorical borders, all classificatory limits. The garden gives expression. That is to say, life'. ${ }^{33}$

And so it is thanks to your gift of the anenome that I returned not only to HC's garden in Arcachon but to the Jardin d'Essai in So Close, which 'is', she insists, 'a natural fiction. It is the Dream of the Most Beautiful Garden in the World' ${ }^{34}$ But it is also a garden that she has not visited since childhood, although memories of it from her father and from Derrida remain palpable: the garden is 'bewitching'; the 'peppery scent of the terebinth' is 'unforgettable'; it has attained mythological powers, where 'an insurrectional fluid is mixed up with its sap'. ${ }^{35}$ Playing in the text on the presence of his initials within the Jardin $d$ 'Essai, she explains that although she and Derrida have never been to the garden together, they have visited 'dozens of times. By dint of citing it and describing it, we have brought it to the mythological summit'. ${ }^{36}$ 'Together, we look at the garden', she writes in Rootprints, and this real garden is the place of the text. ${ }^{37}$ And yet despite this, it seems at times that this garden takes to the air or hides, perhaps, in its own undergrowth. In Illa, she admits, 'I could not find it. I tried and tried [j'essayai et j'essayai], I invented a whole garden of names without success' ${ }^{38}$ It is a search that she continues in So Close, but her path is circuitous, the voylage/voilage ${ }^{39}$ full of detours, false stopping points and concealed entrances. Her 'counterchauffeur' Wahib attempts to follow the directions she obtained from Derrida's brother, first to their house, and then to the cemetery. But 'where you want to go man would have to fly', Wahib tells her: 'Exactly, I say. Let us fly'. ${ }^{40}$ (Up in the air again!) Eventually, she sees the garden's 'brilliant greens rolling down toward the sea from the parapets' and 'its palaces of overpopulated foliage'. But rather than heading to the main gates, she directs Wahib to 'the hidden gate', through which 'one can slip into the supernatural'. What she does not know, however, as she stands before 'the secondary gate' is that any entrance to the 'real' Jardin d'Essai is forbidden (it was closed to visitors for restoration works between 2001 and 2009). Facing 'the high dull fences', HC writes: 'My whole internal space is taken up by the bars'. 'I was born with Garden Forbidden', she despairs, admitting, 'I am jealous of a seagull that enters the Garden through the air'. ${ }^{41}$

So is it just a coincidence, do you think, that our phone call that day also arrived in the garden, in HC's garden in Arcachon, though we did not enter by the main gate, but on a bird's wing? Perhaps the internet blackspot in Arcachon was another concealed entrance, for without it, we would never have found our way through its impossible terebinth, its giant ficus, its violets, mimosas, and naturally its hidden gates. And still I envy that seagull who not only taps her line but enters her garden from the sky. 
$\mathrm{CB}::$ :

I'm beginning to enjoy the elongated pip of the answerphone and the automated voice reading out your digits and asking me - please, she implores - to leave a message. A part of me feels that she is also calling, sending something, this recorded woman who speaks - and each time, when she answers, I imagine that her voice is just slightly, imperceptibly different.

This time, I'm calling from the garden. Or rather, it's the garden re-calling. The garden is where everything begins and to where, as HC suggests again and again in her work, we inevitably return ('revenons' is a word that grows everywhere in her oeuvre - a beautiful, unstoppable weed). And she has discovered so many paths in and out of there: she's a pioneer of the dangerous lost ways. For example, she knows that a book, writing, is a line-out - a shortcut to-and-from the garden. In Philippines, she (or some other caller) calls out, in prayer:

Books, deliver us, make us delirious [livres, délivrez-nous, délirez-nous], lead us into the garden of Unland where the flowers grow whose adored names we had forgotten, where under the clumps of thyme perhaps or between the stalks of acanthus, I find the keys to the gates of immortality. ${ }^{42}$

This is a strange address, a telephone call to 'Books', those plant-based growths, who are always on the other line. What's she calling for? It is something about gardens and writing, plants and poetry - this desire to be led astray. This is always the way with writing; immediately, from the moment we pick up, we are off, away - teleported into the undergrowth. We become like Socrates in Plato's Phaedrus, who, as Derrida observes, is compelled by the pharmakon (i.e. writing) to leave the city and enter a space where human rules and ways have little purchase: 'Operating through seduction, the pharmakon makes one stray from one's general, natural, habitual paths and laws'. ${ }^{43}$ So Socrates finds himself in Unland, too, in spite of his better judgement. What, then, is Unland? A kind of no-man'sland, a place of negation: the place of appels en absences, powered by the 'un' (which is a close friend of the French prefix 'dé'). It's where 'uns' are born and kept - a nursery of sorts. Freud says in his essay on 'The "Uncanny"': 'the prefix 'un' is the token of repression'. ${ }^{44}$ (He might well say the flower of repression.) The garden of Unland is the underland of all we have had to forget, and to go there, we must become, delirous: it un-books (délivrer) and unreads (délirer) us. (I don't need to tell you this, but it's where the ULO begins to bloom.)

We find ourselves in the undergrowth of writing and living, among unnamed flowers (named 'un') and a few other vegetables: 'stalks of acanthus' and 'clumps of thyme'. How have they come to take root in this Imaginary? The acanthus (possibly from the Greek $\ddot{\alpha} \kappa \alpha \nu \theta \alpha$, meaning 'thorn') is a prickly, rigid, but also mighty and ancient, plant. In her Tribute to Freud, H.D. describes the entrance to Freud's building on Berggasse in Vienna: 'there were patterns, decorative hieroglyphs of acanthus leaves, a very classical symbol' ${ }^{45}$ H.D. (like HC) is interested in the thorniness of analysis: she finds in it something unyielding, unfruitful. Passing through the gates, she follows the spiny acanthus leaves into the first garden:

There was the ground, cursed by God because Adam and Eve had eaten the Fruit of the Tree. Henceforth, it would bring forth thorns and thistles - thorns, thistles, the words conjure up the same scene, the barren, unproductive waste or desert. Do men gather grapes of thorns, or figs of thistles? ${ }^{46}$ 
These thorn-plants - which grow up and take centre-stage in Cixous' Unland - are, for H.D., a mark of something inhuman: they are after the garden, poisoning it. That which is inedible, inutile and merely decorative ('unproductive waste') is a punishment afflicted upon those who stray from the proper path. Hardship is likely: death, henceforth, is certain. And yet, paradoxically perhaps, the thorn/thistle is also a magic key or symbol. This dangerous in- or un-humanity opens the portals (like a code or telephone number): of psychoanalysis - and immortality. Indeed, it is said that the acanthus, for the Ancient Greeks and Romans, signified 'enduring life'. ${ }^{47}$ The logic overgrows itself: to live we must begin to die. Death shall be dethroned, ${ }^{48}$ perhaps, but never dethorned.

Quickly, before I go: a paronomasic note on 'thyme'. Naturally it doesn't work in the original French but, in English, 'time', too, becomes a shrub, beginning to grown in 'clumps'. So it is 'under' time, 'or between', that (un)mortality might be found - under and between calls, words - letters, too. Thyme is a plant that crops up elsewhere in HC's writing. The word leads us, and leads Cixous' auto-narrator, back in time. It returns us to the Clos-Salembier and the prehistoric gardens of childhood. But let's be clear from the outset: the garden of the past is necessarily painful and difficult to enter. Revenir is an irresistible, but also thorned, word. As Elizabeth Anderson notes: 'Cixous does not consider the garden to be the site of pre-lapsarian perfection and innocence; rather, she chooses the inside of the fruit, to taste and to know'. 49

In particular, I'm thinking of a moment in Reveries of the Wild Woman, where the memory of the garden is one of losing oneself to a queer (non)knowledge. At the gates of the garden, the child says: 'I yank off tufts of thyme eyes averted I push thyme through the gate, so not to see myself not giving holding out the thyme in the hand held out to take the thyme'. ${ }^{50}$ Thyme (from thuein) means 'burn' or 'sacrifice': it has a ritualistic history. The child's offering of thyme, a deadly game, is about sacrificing or burning oneself at the gate: it's the 'I' that gets it here. The amphibology of this sentence creates phantom limbs or branches, grows phantom others/selves. Who is receiving this thyme being given by whom? The one who receivesgives thyme (time) is always absent from the scene/seen (another appel en absence). Time and thyme again, she repeats these unseen scenes in the gardens of time and memory. As if something's been lost that she's trying to unfind. In search of lost thyme (forgive me!).

SJ : : :

Speaking of lost time/thyme returns us to the event, and to the thorny issue of the after-event. After we hung up, not immediately after but later, while we were still in the midst of some kind of autopsy, a man raised his trunk and asked about an elephant in the room. Elephant? You must mean telephant, I thought, telephant in the garden, recalling the transmissibility between the animal and the telephone in the work of Cixous that Derrida describes in H.C. for Life: 'animals are telephones and sometimes the other way around, and they multiply, in the prolifauny of all their animal, human, and divine metamorphoses'. ${ }^{51}$ In 'From My Menagerie to Philosophy', HC dials her cat Thea by whistling 'three notes like this : : :', but on that day, I imagined her ringing back after the event on her telephant, joining the conversation on a trunk line. ${ }^{52}$ Perhaps this isn't the elephant to which the man was referring, but I have to admit he was on to something: like telephones, there are of course animals and plants everywhere in HC's work. ${ }^{53}$ And there is something phantasmatic about this particular elephant and the way that it continues to haunt our call. Derrida explains that 'the exemplary privilege of the elephant, of this trope and of this trunk is in the fact that it is both a living animal and bears in its name the root simulacrum of the very simulacrum, of the phantasma, 
of the seeming, and of the spectral, ${ }^{54}$ Reiterating this link with the spectral in his fable of the elephant and the king in The Beast and the Sovereign, he leads us to the autopsy chamber to gaze into the eye of the 'elephenomenelephant'. ${ }^{55}$ Recalling this scene, and stressing once again the link between the elephant and eulogy, between remembering and forgetting, Kelly Oliver returns us to the 'elephant revenant', calling on all the telephantasms in the room. ${ }^{56}$ And the elephant in the room was, of course, a telephant in the garden; connected via a trunk line, this elephant was always already hooked to the telephone. Both living event and primal elefantasy, HC's telephantasmatic presence after the event set in motion a switchboard that would connect up all kinds of extraordinary and non-human ears.

Beyond human hearing, yes, but if animals are telephones and sometimes the other way around, to what extent can plants be said to have telephonic properties? We know that a stalk of corn has ears, but do plants talk back? From Erasmus Darwin's 1789 personification of the vegetal in The Loves of the Plants to recent scholarship by Richard Karban on plant communication, philosophers, scientists and writers are drawn to what Gagliano, Ryan and Vieira call a 'vegetal textuality'. ${ }^{57}$ Describing 'talking flower heads' in The Telephone Book, for instance, Avital Ronell points out that Thomas Watson - who assisted Alexander Graham Bell in his early experiments on the telephone - is hooked up to the vegetal. ${ }^{58}$ She's referring to his autobiographical account of the 'touches of beauty' in his impoverished childhood home, 'especially the morning-glories my mother grew in our tiny back yard' ${ }^{59}$ In Exploring Life, Watson goes on to comment on his early 'spiritual insight' when the morning-glories 'suddenly [...] began to talk to me'. ${ }^{60}$ Robert Frost, too, writes of the telephonic properties of the daffodil in 'The Telephone', in which he describes 'an hour / All still / When leaning my head against a flower / I heard you talk' ${ }^{61}$ And of course, Cixous talks to the mimosa - the 'body-language' of the flower that, Calle-Gruber remarks, 'has shaped Hélène Cixous' books for a long time'. ${ }^{62}$ Describing it as 'once a mimer, a "mimeuse", for the way that this sensitive plant appears to mimic an animal's response to touch, $\mathrm{HC}$ draws attention to its capacity to communicate. ${ }^{63}$ Recalling her mother Eve leaving a bouquet of mimosas, which she adores, on her kitchen sink, she notes, 'I feel the perfume of mimosa speaking. I feel life'. ${ }^{64}$ It speaks, and yet the 'mimosa is ephemeral. It will be dead tomorrow', she says, reminding us of the ephemerality of our own call. ${ }^{65}$

It is in 'The Last Painting', however, that HC links the mimosa and the telephone, leaving me to wonder the extent to which the mimosa, like Frost's daffodil and Watson's morning-glory, is the telephone. Comparing the painter's ability to show 'what is living in life', HC argues that in writing she "paint[s] in a different way'. ${ }^{66}$ What she wishes so much to show her interlocutor is the mimosa:

I'm calling: Mimosa! I'm calling you.

I tell you on the telephone: I want so much for you to see the mimosas. I send you the word 'mimosa;' I hope that one delivered to your breast, it will transform itself into a vision of mimosa. I am a being who paints mimosas by phone. ${ }^{67}$

Reading the ambivalence of the colon in this call, can we not also argue that $\mathrm{HC}$ at the same time telephones the mimosa? Dialling-up in this way, the mimosa becomes the receiver - a mimosophone. Moreover, Calle-Gruber argues that 'to give a body of letters the word "mimosa" is to make it unforgettable because call-able, spellable, recallable'. ${ }^{68}$ Calling the mimosa, naming it, is to recall it to the present, which is what we've been trying to do all along, isn't it? Who's calling there? I'm calling: Mimosa! I'm calling you. 
$\mathrm{CB}::$ :

Missed you again. This time: I was on another call. On the other line, HC, in the guise of a flower, calls to me: 'we forget how plants are called before we think to call them and recognise them, we have forgotten that it is plants that call us, when we think about calling them, that come to meet our bodies in blossom'. ${ }^{69}$ You know, of course, that I'm also interested in silent calls, the calls that vegetate, speak-without-speaking, signify in ways not meant for us. I listen with my vegetable ears, catching rerouted calls. Long before scientists started talking about plant sentience, communication and the 'Wood Wide Web', HC avowed that plants call us up. I'm remembering something else from our lost call: 'plants cultivate us', she said. I wrote it down, felt cultivated by it.

On the topic of unexpected callers, Avital Ronell asks: 'who suffers, who speaks, who sends out an SOS or call for help, who intercepts, and what kind of communication systems have to be reconstructed when you assume that the listening, launching, or receptor-other is nonhuman or anahuman? ${ }^{70}$ This is also what your interrupting birdcalls and morning(mourning?)-glories made me think about. How to reprogramme our ears, our lines of flight, our pathways of thought, in order to receive and read this song - loud and clear? And what if that 'listening, launching, or receptor-other' is a vegetal ULO? How can we possibly hear what it has to say? JD calls HC's unforeseeable writing a 'meteorite' fallen to earth, arriving in the garden. But I'm also starting to think of the ULO as something we're digging up in the flowerbeds. It was perhaps already here, calling, flowering: growing quietly and undisturbed, yet always waiting on the line for us. It keeps growing, launching, dialling, even after we uproot it.

'Let's return - revenons', ${ }^{71}$ Cixous says this everywhere in every way. Returning, I'll try to pick up where you left off earlier - with the garden, together: together we look at the garden. HC speaks of the garden to Mireille Calle-Gruber, her interlocutor in Rootprints:

We could express this place in a thousand ways. Relations of colours together; of different species together; between the vegetable and the human. In relation to all the phenomena of growing, to the question of preservation. Gardening is an act that is absolutely strange, in relation to life and death. And if I only listen to myself gardening, I have a very light sense of suffering in saying to myself: why garden when I know it will die? That, for me, is the other. Between us: death. Together we look at the garden. ${ }^{72}$

There is no garden without a 'together' and vice versa. It is already a place where paths cross endlessly. It's where 'we' meet the vegetable, but also each other (as vegetable?). In Cixous the garden is the place where everything takes off: it is where ' $I$ ' begins (and ends). She listens 'to [her]self gardening'. There's a weird convergence at work between the English word 'garden' and the French 'garder'. Cixous' gardens often come with guards. At the gardens of the Cercle Militaire in Oran, a 'superior force' guards the garden, 'keeps [her] from being truly inside'. And within the garden itself, the other (non-Jewish) children also become guards: 'they do not admit me'. ${ }^{73}$ This is re-played in the confinements of Cixous' 'A Real Garden', where 'keepers of the paths [les gardiens des allées]' are employed to scope out otherness and keep 'trash' (that is to say, the narrator, who is an outsider-inside) off the footways. ${ }^{74}$ In this text, the narrator, a boy-girl who lives out their days in a walled garden (resembling in many ways that of the Cercle Militaire), teased and physically abused by the 
guards and nursemaids, becomes un-human as a result of their untouchability: 'Once I was still on the edge of the animal kingdom, now I was being pushed back to the indefinable'. ${ }^{75}$ Gardening necessitates violence, a decision about what is admissible and what must be kept out or killed (being 'indefinable', outside the law).

Reading with you, to you, I want to ask what we have been gardening/guarding (against) here together? What has been growing and what 'together' do we seek to preserve? Gardens are demanding, they demand keeping (gardant). They keep demanding. Together we keep calling, demanding of each other. 'Together' worries me. In the French, 'ensemble', it's to do with time - with doing something at the same time (it comes from late Latin in + simul 'at the same time'). The French suggests completeness, simultaneity, synchronicity. This is misleading. It tricks us into believing that this is somehow a safe pursuit, this togetherness. In English, 'together' connotes foraging and collecting, being etymologically related to 'gather'. We gather together, perhaps picking, in tandem, a nosegay of signs from the garden. But gathering up also seems to suggest that something might be missed, something falls between the cracks of 'together'. And as Venus says to Adonis in Shakespeare's rendering of the myth: 'Fair flowers that are not gather'd in their prime / Rot and consume themselves in little time'. ${ }^{76}$

Cixous writes about the language that exists between her and Derrida: 'from the beginning between us the question of French, the common gesture regarding the French language, a kind of effraction / The gesture that we make together differently together'. ${ }^{77}$ This 'gesture' it's a shared crime, a burglary ('effraction') or break-in. HC-and-JD - they make it past the guards together, making the same moves, gestures: it is synchronised housebreaking. But the adjective 'effracted' also means 'broken off'. 'Together' is necessarily broken, elliptical. For, as Cixous demonstrates, between 'together' dwells 'differently'. There's no guarding against this. To talk, think, write 'together', as we have been trying (essayer), is to walk along the telepaths of the garden. And yet we always fail to gather - the air of rotting flowers rises up.

Between us:

\section{SJ : : :}

Yes. But although the garden is, as you say, a place of death, its language, Calle-Gruber points out, makes '(a) present each time again'. The garden, she goes on, 'does not forget the forgetting, retains the trace of loss'. As a place for remembrance, then, the garden recalls 'a memory of the absenting' ${ }^{78}$ And you're right about the guards, too. Finding they are forbidden from entering the Jardin d'Essai in So Close, HC despairs. But Wahib is insistent, persuading the guard sitting on the steps of a white sentry box to let them enter: 'Rapidman! yells the guardian on his side' and they 'run into the arms of the first tree we come to, this dracaena with nine arms that it spreads for me'. ${ }^{79}$ Though her excursion is transitory, rapid, though she embraces only one tree, she 'touch[es] the sky', and as she does, this narrative morphs for an instant with the one written more than thirty years earlier, about the 'real garden': 'I was the garden, I was inside [...]'. ${ }^{80}$

But in thinking about what we have been gardening/guarding (against) here together, it's worth noting that $\mathrm{HC}$ describes the guard at the Jardin d'Essai as a 'guardian'. 'Garder is to save, to guard, to preserve,' writes Alan Bass. Explaining that 'in German Warhrheit, truth, is related to Wahren, to preserve', he goes on to point out that 'to preserve and to reserve are etymologically the same, from the Latin reservare, to keep back'. He's writing about the 
problem of preserving the letters that make up 'Envois' in The Post Card: 'to save the letters or to burn them? ${ }^{81}$ It's a question we might ask of these voicemails: to save or to burn, to preserve or to keep back?

We keep trying to recall - and to try to find a way to preserve - the lost trace of HC's call, but as HC says of the letter, the telephone message is 'always virtually posthumous. Between departure and arrival how much time, how many years, and even death. ${ }^{, 82}$ We have agreed to safeguard these messages, but in recalling the call and gathering together this nosegay of signs, there is always death between us: Camilla, my mimosa, were we at the end of the line from the beginning?

$\mathrm{CB}::$ :

I know I'm only playing with words here, getting snared on a few thorns on my way to something greater, which I still cannot identify. It's like digging out a couple of weeds from an endless, overgrown garden. It's hard to gather anything, and yet we must keep on. Keeping, guarding, warding, preserving are necessary activities for living, but also writing gardening, or guarding against is writing itself. And yet HC avows: 'I know it will die'. She gathers herself against the inevitable, playing with death. We're back in the gardens of Adonis, those seeds planted with nowhere to grow. I'm getting to the end, too. I'm beginning to realise that the garden is the closest place to death. The garden is always almost a cemetery. And when Cixous says 'it will die' she also means 'I will die'. We tend the cemetery-garden for ourselves. Dig our own graves in the flowerbeds.

Cixous tells us that 'Kafka's last thoughts were for flowers. It's all the more remarkable because there are not many flowers in his texts' ${ }^{83}$ At the end, Kafka wrote flowers on tiny slips of paper (published as 'Conversation Slips') because he could no longer speak. Like Kafka's final 'slips', I've been speaking to you in an ephemeral way, in torn petals or scraps - meagre and unsatisfactory, I know - hoping to slip away or be discarded like waste, trash. On Kafka's final fascination with the floral, Cixous wonders: 'Perhaps flowers are our last human stage'. ${ }^{84}$ We return to the flowers within us: we climb for dear life onto the branches of a magnolia tree. We grow into the arms of the unidentifiable. I too am losing the will or way to speak and live. There's (no) more to say. Just one last word -

\section{Bibliography}

Anderson, Elizabeth. H.D. and Modernist Religious Imagination: Mysticism and Writing. London: Bloomsbury, 2013.

Aristotle, Complete Works of Aristotle: The Revised Oxford Translation. Edited by Jonathan Barnes. Princeton: Princeton University Press, 1984.

Barbour, Charles. Derrida's Secret: Perjury, Testimony, Oath. Edinburgh: Edinburgh University Press, 2017.

Bass, Alan. 'Translator's Introduction.' In Jacques Derrida, The Post Card: From Socrates to Freud and Beyond. Translated by Alan Bass, ix-xxx. Chicago: The University of Chicago Press, 1987. 
Browne, Janet. 'Botany for Gentlemen: Erasmus Darwin and "The Loves of the Plants".' Isis 80, 4 (1989): 593-621.

Calle-Gruber, Mireille. 'The Book Inside the Book.' Translated by Sophie Thomas. Oxford Literary Review 24, 1 (2002): 71-95.

Chwalkowski, Farrin. Symbols in Arts, Religion and Culture: The Soul of Nature. Newcastle: Cambridge Scholars, 2016.

Cixous, Hélène. Abstracts and Brief Chronicles of the Time: Los, a Chapter. Translated by Beverley Bie Brahic. Cambridge: Polity, 2016.

Cixous, Hélène. 'The Book as One of Its Own Characters.' Translated by Catherine Porter. New Literary History 33, 3 (2002): 403-434.

Cixous, Hélène. 'Clarice Lispector: The Approach.' Translated by Sarah Cornell and Susan Sellers. In Coming to Writing and Other Essays, edited by Deborah Jensen, 59-77. Cambridge, MA: Harvard University Press, 1991.

Cixous, Hélène. Death Shall Be Dethroned: Los, a Chapter, the Journal. Translated by Beverley Bie Brahic. Cambridge: Polity, 2016.

Cixous, Hélène. 'From My Menagerie to Philosophy.' Translated by Keith Cohen. In Resistance, Flight, Creation: Feminist Enactments of French Philosophy, edited by Dorothea Olkowski, 40-48. Ithaca: Cornell University Press, 2000.

Cixous, Hélène. Hemlock: Old Women in Bloom. Translated by Beverley Bie Brahic. Cambridge: Polity, 2011.

Cixous, Hélène. Illa. Paris: des femmes, 1980.

Cixous, Hélène. Insister of Jacques Derrida. Translated by Peggy Kamuf. Stanford: Stanford University Press, 2007.

Cixous, Hélène. 'The Last Painting or the Portrait of God.' Translated by Sarah Cornell and Susan Sellers. In Coming to Writing and Other Essays, edited by Deborah Jenson, 104-131. Cambridge, MA: Harvard University Press, 1991.

Cixous, Hélène. Love Itself in the Letterbox. Translated by Peggy Kamuf. Cambridge: Polity, 2008.

Cixous, Hélène. Philippines. Translated by Laurent Milesi. Cambridge: Polity, 2011.

Cixous, Hélène. 'Preface: On Stigmatexts.' Translated by Eric Prenowitz. In Stigmata: Escaping Texts, $\mathrm{x}-\mathrm{xiii}$. London: Routledge, 2005.

Cixous, Hélène. 'A Real Garden.' Translated by Beverly Bie Brahic. In The Portable Cixous, edited by Marta Segarra, 71-77. New York: Columbia University Press, 2010.

Cixous, Hélène. Reveries of the Wild Woman: Primal Scenes. Translated by Beverley Bie Brahic. Evanston: Northwestern University Press, 2006.

Cixous, Hélène and Mireille Calle-Gruber. Rootprints: Memory and Life Writing. Translated by Eric Prenowitz. London: Routledge, 1997.

Cixous, Hélène. So Close. Translated by Peggy Kamuf. Cambridge: Polity, 2009.

Cixous, Hélène. Three Steps on the Ladder of Writing. Translated by Sarah Cornell and Susan Sellers. New York: Columbia University Press, 1993.

Cixous, Héléne. '(With) Or the Art of Innocence.' Translated by Stephanie Flood. In The Hélène Cixous Reader, edited by Susan Sellers, 93-104. London: Routledge, 1993.

Cixous, Hélène. The Writing Notebooks. Edited and translated by Susan Sellers. London: Continuum, 2004.

Cixous, Hélène and Nicholas Royle. In conversation (7 June 2011). Accessed 14.01.2019. http://www.sussex.ac.uk/video/schools/english/HeleneCixousOnTheTelephone.mp3

Darwin, Erasmus. The Botanic Garden Volume II: The Loves of the Plants. Edited by Adam Komisaruk and Allison Dushane. London: Routledge, 2017.

Deleuze, Gilles and Félix Guattari. A Thousand Plateaus: Capitalism and Schizophrenia. Translated by Brian Massumi. London: Continuum, 2004. 
Derrida, Jacques. The Beast and the Sovereign, Vol. I. Translated by Geoffrey Bennington. Chicago: University of Chicago Press, 2009.

Derrida, Jacques. Dissemination. Translated by Barbara Johnson. London: Continuum, 2004.

Derrida, Jacques. H.C. for Life, That Is to Say.... Translated by Laurent Milesi and Stefan Herbrechter. Stanford: Stanford University Press, 2006.

Derrida, Jacques. 'Literature in Secret: An Impossible Filiation.' In The Gift of Death and Literature in Secret. 2nd edition. Translated by David Wills, 117-158. Chicago: University of Chicago Press, 2008.

Derrida, Jacques and Hélène Cixous. 'From the Word to Life: A Dialogue Between Jacques Derrida and Hélène Cixous'. Translated by Ashley Thompson. New Literary History 37, 1 (2006): 1-13.

Freud, Sigmund. 'The "Uncanny".' In The Standard Edition of the Complete Psychological Works of Sigmund Freud, Volume XVII, edited and translated by James Strachey, 217-252. London: Hogarth Press, 1955.

Frost, Robert. 'The Telephone.' In Mountain Interval, 24. New York: Henry Holt, 1921. Gagliano, Monica, John C. Ryan and Patrícia Vieira, 'Introduction.' In The Language of Plants Science, Philosophy, Literature, edited by Monica Gagliano, John C. Ryan and Patrícia Vieira, vii-xxxiii. Minneapolis: University of Minnesota Press, 2017.

H.D. Tribute to Freud. New York: New Directions, 2012.

Karban, Richard. Plant Sensing and Communication. Chicago: University of Chicago Press, 2015.

Oliver, Kelly. 'Elephant Eulogy: The Exorbitant Orb of an Elephant.' In The Animal Question in Deconstruction, edited by Lynn Turner, 89-104. Edinburgh: Edinburgh University Press, 2013.

Reitzammer, Laurialan. The Athenian Adonia in Context: The Adonis Festival as Cultural Practice. Madison: University of Wisconsin Press, 2016.

Ronell, Avital. The Telephone Book: Technology, Schizophrenia, Electric Speech. Illinois: University of Nebraska Press, 1989.

Ronell, Avital and Diane Davis. 'Breaking Down "Man": A Conversation with Avital Ronell.' Philosophy and Rhetoric, 47, 4 (2014): 354-385.

Royle, Nicholas. 'Away.' parallax, 13, 3 (2007): 94-103.

Shakespeare, William. Hamlet. Edited by Harold Jenkins. London: Methuen, 2002.

Shakespeare, William. 'Venus and Adonis.' In The Complete Sonnets and Poems, edited by Colin Burrow, 175-236. Oxford: Oxford University Press, 2008.

Watson, Thomas A. Exploring Life: The Autobiography of Thomas A. Watson. New York: D. Appleton, 1926.

\section{Notes}

1. This refers to the symposium on the 'Unidentifiable Literary Object' held on 29 June 2018 at Nottingham Trent University.

2. Cixous, Insister of Jacques Derrida, 149-150.

3. Cixous, Love Itself, 42.

4. Ibid., 42, 43.

5. Ibid., 42.

6. Derrida, H.C. for Life, 10.

7. Cixous, '(With) Or the Art of Innocence,' 102.

8. Cixous, Love Itself, 111. 
9. Aristotle, History of Animals, 871.

10. Derrida, Dissemination, 184.

11. Ibid., 150 [my emphasis].

12. See Reitzammer, The Athenian Adonia in Context.

13. Derrida, Dissemination, 151.

14. Shakespeare, Hamlet, 2.2.519-20. See also Cixous, Abstracts and Brief Chronicles of the Time: I: Los, A Chapter.

15. Cixous and Royle, in conversation.

16. Cixous, Three Steps on the Ladder of Writing, 111.

17. I wonder if the telephone also has wings.

18. Derrida, 'Literature in Secret,' 119, 125.

19. Ibid., 130, 133, 131.

20. Ibid., 140. Derrida is referring here to the biblical story of Abraham and Isaac in Genesis (22: 10-13).

21. Ibid., 133.

22. Derrida and Cixous, 'From the Word to Life,' 3.

23. Derrida, 'Literature in Secret,' 139.

24. Barbour, Derrida's Secret, 140.

25. Derrida, 'Literature in Secret,' 133.

26. Ibid., 139.

27. Cixous and Royle, in conversation.

28. Deleuze and Guittari, A Thousand Plateaus, 9 and passim.

29. We also find a version of this fugitive tale in Hemlock: Old Women in Bloom, when the narrator recalls a 'dead branch that makes my mother laugh to tears because for a moment she sees herself clambering up into the tree and removing this thorn from her eye' (Hemlock, $55)$.

30. See Royle, 'Away,' 94-103.

31. Derrida, H.C. for Life, 7.

32. Cixous, Rootprints, 13.

33. Calle-Gruber, 'The Book Inside the Book,' 77.

34. Cixous, So Close, 65.

35. Ibid., 135.

36. Ibid., 64-65.

37. Cixous, Rootprints, 13.

38. Cixous, Illa, 139, cited in Derrida, H.C. for Life, 151.

39. Cixous, So Close, 111.

40. Ibid., 128.

41. Ibid., 134-6.

42. Cixous, Philippines, 6-7.

43. Derrida, Dissemination, 76.

44. Freud, 'The "Uncanny", 245.

45. H.D., Tribute to Freud, 89.

46. Ibid., 88.

47. Chwalkowski, Symbols in Arts, Religion and Culture, 182.

48. See Cixous, Death Shall Be Dethroned.

49. Anderson, H.D. and Modernist Religious Imagination, 128.

50. Cixous, Reveries of the Wild Woman, 65.

51. Derrida, H.C. for Life, 169. 
52. Cixous, 'From My Menagerie to Philosophy,' 48.

53. See references to the elephant in, for instance, Cixous, The Writing Notebooks, 19.

54. Derrida, H.C. for Life, 103.

55. Derrida, The Beast and the Sovereign, 282.

56. Oliver, 'Elephant Eulogy,' 91.

57. Darwin, The Botanic Garden Volume II: The Loves of the Plants. See also: Browne, 'Botany for gentlemen,' 593-621; Karban, Plant Sensing and Communication; Gagliano, Ryan and Vieira, 'Introduction,' xvi.

58. Ronell, The Telephone Book, 242.

59. Watson, Exploring Life, 6.

60. Ibid., 14-15.

61. Frost, 'The Telephone'.

62. Calle-Gruber, 'The Book Inside the Book,' 88.

63. Cixous, 'The Book as One of Its Own Characters,' 428.

64. Ibid., 430.

65. Ibid., 428.

66. Cixous, 'The Last Painting,' 105, 106.

67. Ibid., 106-107.

68. Calle-Gruber, 'The Book Inside the Book,' 88.

69. Cixous, 'Clarice Lispector: The Approach,' 65.

70. Ronell and Davis 'Breaking Down 'Man”,' 357.

71. Cixous, Philippines, 1.

72. Cixous, Rootprints, 13.

73. Cixous, 'Preface: On Stigmatexts,' xv.

74. Cixous, 'A Real Garden,' 71-2.

75. Ibid., 77.

76 William Shakespeare, 'Venus and Adonis,' 182.

77. Cixous, Insister of Jacques Derrida, 87.

78. Calle-Gruber, 'The Book Inside the Book,' 76.

79. Cixous, So Close, 137.

80. Ibid., 137; Cixous, 'A Real Garden,' 77.

81. Bass, 'Translator's Introduction', xxii.

82. Cixous, 'The Book as One of Its Own Characters,' 420.

83. Cixous, Three Steps on the Ladder of Writing, 151.

84. Ibid. 